\title{
Toxicity of epoxiconazole to the marine diatom Chaetoceros calcitrans : influence of growth conditions and algal development stage
}

\author{
Anis Amara ${ }^{a, b, d, ~}{ }^{*}$, Françoise Quiniou ${ }^{b}$, Gaël Durand ${ }^{c}$, Monia El Bour ${ }^{d}$, Abdellatif Boudabous $^{\mathrm{e}}$ and \\ Annick Hourmant ${ }^{\mathrm{a}}$
}

\author{
${ }^{a}$ Lab. de Toxicologie Alimentaire et Cellulaire, UFR Sciences et Techniques, C.S. 93837, 29238 Brest, Cedex 3 , \\ France. Université Européenne de Bretagne. \\ ${ }^{b}$ Ifremer, Department of Biogeochemistry and Ecotoxicology, 29280 Plouzané, France \\ c IDHESA, B.P. 52, 29280 Plouzané, France \\ d INSTM, Lab. de Pathologie des Organismes Aquatiques, Salammbô, Tunis \\ e Lab. de Microorganismes et Biomolécules Actives, Fac. des Sc. de Tunis, 2092 Tunis \\ *: Corresponding author : Anis Amara, email address : anisamara@yahoo.fr
}

\begin{abstract}
:
The triazole fungicide epoxiconazole is extensively used to control fungi on crops and may present some potential risk from runoff on coastal ecosystems located close to agricultural areas. Phytotoxicity assessments were conducted on the marine diatom Chaetoceros calcitrans using both the active ingredient and its formulated product (Opus). The 3-day EC50 using cell count was $2.31 \mathrm{mg} / \mathrm{L}$ for epoxiconazole active ingredient and $2.9 \mu \mathrm{g} / \mathrm{L}$ for epoxiconazole-formulated. The fungicide produced an increase of cellular volume, pigment (chlorophylls a, c, and carotenoids) content, ATP synthesis, and rates of photosynthesis and respiration. Progressive algal cell recovery from epoxiconazole effects occurred after 3 days, with the increasing cell density. Differences in cell age, light, and nutrient composition induced changes in epoxiconazole sensitivity. Since these parameters affect cellular division rates, the cellular density is an important parameter in toxicity tests.
\end{abstract}

Keywords: Age cell ; Chaetoceros calcitrans ; Culture conditions ; Epoxiconazole ; Growth ; Physiological parameters 


\section{Introduction}

Epoxiconazole (CAS registry number 133855-98-8), a systemic triazole fungicide, is commonly used in the world to control fungi and to regulate plant growth in a number of economically important crops such as cereals, fruits, grapes (Ammermann et al., 1992; Schöfl \& Zinkernagel, 1997; Bertelsen et al., 2001). This broad-spectrum fungicide inhibits the cytochrome P450-mediated C14 demethylase reaction, crucial to the formation of ergosterol, component of fungal cell membrane (Akers et al., 1990; Kwok \& Loeffler, 1993).

Several studies report on the physiological effects of epoxiconazole in higher plants, however, most of them are related to its use in agriculture (Benton \& Cobb, 1997; Wu \& Von Tiedemann, 2001; Percival \& Noviss, 2008). Epoxiconazole is very persistent in soil and aquatic sediment (Bromilow et al., 1999; Tomlin, 1999; Lin et al., 2001; AGRITOX, 2010; Passeport et al., 2011) and could lead to accumulation. Following repeated applications, it enters adjacent freshwater ecosystems from spraying, leaching and run-off, making its way to estuarine and marine areas. As a consequence, the introduction of this xenobiotic pollutant into the marine environment may lead to serious noxious effects on non-target aquatic organisms, including phytoplankton.

The potential threat of epoxiconazole on aquatic ecosystems has raised considerable concern, and the toxicity of epoxiconazole on fish, Daphnia, freshwater algae (AGRITOX, 2010) and oyster (Stachowski-Haberkorn et al., 2008) has been studied. Moreover, epoxiconazole may interact synergically with an herbicide (Stachowski-Haberkorn et al., 2008) or a pyrethroid insecticide towards D. magna (Nørgaard \& Cedergreen 2010).

Phytoplankton is dominated by microalgae which play an important role in the equilibrium of marine ecosystems, being at the basal level of food webs and the starting point of trophic transfer (Zeitzschel, 1978). In a recent report, Baird \& DeLorenzo (2010), have shown that Dunaliella tertiolecta was especially susceptible to four conazole fungicides. Up to now, data on toxicity effects of epoxiconazole on marine microalgae are relatively sparse, only a genotoxic effect on the dinoflagellate Karenia mikimotoi (Akcha et al., 2008) and changes in phytoplancton communities (Stachowski-Haberkorn et al., 2009) have been reported. Because microalgae are highly sensitive even to low doses of toxic chemicals, the selected algal species is the diatom Chaetoceros calcitrans, representative of the field communities of concern in Tunisia.

This study provides insight on the sublethal effects of epoxiconazole alone and its formulation to the physiology of a non-target algal cell.

\section{Material and methods}

\subsection{Microalgal culture}

Chaetoceros calcitrans was obtained from Ifremer (Brest, France) and was maintained in a f/2 medium (Guillard \& Ryther, 1962). The inoculum $\left(0.2 \times 10^{4}\right.$ to $10^{4}$ cells $\left./ \mathrm{ml}\right)$ was taken from the logarithmic phase and cultures were grown in $1 \mathrm{~L}$ Pyrex glass bottles containing 500 $\mathrm{ml}$ of culture medium.

Two culture mediums were used in toxicity tests: $\mathrm{f} / 2$ and pre-winter Gabès medium. $4.4 \mu \mathrm{M}$ $\mathrm{NaH}_{2} \mathrm{PO}_{4}$ and $8.9 \mu \mathrm{M} \mathrm{NaNO}$ was added to filtered sea water; these nutrient enrichment conditions were determined in accordance with in situ pre-winter measurements taken in the Gulf of Gabès (Tunisia). After autoclaving, sterilized vitamins, $\mathrm{NaSiO}_{3}$, Fe-ethylene diamine tetracetic acid (Fe-EDTA) and metal traces according to Guillard \& Ryther (1962) were 
added. Non-axenic microalgal cultures were maintained at $20 \pm 2{ }^{\circ} \mathrm{C}$ and, depending on experiment, under either a $16 \mathrm{~h}: 8 \mathrm{~h}$ light/dark cycle or a continuous lighting with $60 \mu \mathrm{mol} \mathrm{m}$ ${ }^{2} \cdot \mathrm{sec}^{-1}$ of photosynthetically active radiations (PAR), measured with a light meter (model Li 250, LiCor).

\subsection{Pesticide}

Epoxiconazole (1-[[(2S,3S)-3-(2-Chlorophenyl)-2-(4-fluorophenyl)oxiran-2-yl]methyl]-1,2,4triazole "CAS no 133855-98-8" was purchased from (Dr Ehrenstorfer GmbH, Germany). A stock solution was prepared by dissolving epoxiconazole in dimethyl sulfoxide (DMSO).

A commercial formulation of epoxiconazole : Opus (125 g active molecule per $\mathrm{Kg}$ ) (BASF AGRO SAS) was also tested. A stock solution was prepared by dissolving $10 \mathrm{mg}$ per liter of seawater and sterilized by filtration through a $0.22 \mu \mathrm{m}$ membrane (Millipore).

The effective epoxiconazole concentration was checked in sub-samples. Analyses were performed at the "IDHESA, Brest", using High Performance Liquid Chromatography coupled with a triple quadripole mass spectrometer. The samples were stored frozen in previously burnt glass bottles until use, which was no more than one month.

\subsection{Algal toxicity tests}

Spherical flasks of $250 \mathrm{~mL}$ volume were used for keeping $100 \mathrm{~mL}$ of test medium volume. A range of five concentrations of epoxiconazole was tested and two types of control: flasks with DMSO (active molecule exposure) or without DMSO (formulated product exposure). Three replicates test flasks were used for each treatment and all experiments were performed in triplicate.

To assess the effect of development stage, assays were performed in pre-winter medium culture, under continuous light, and epoxiconazole was added at different times of algae growth : at the beginning ( $\mathrm{d}$ 0), after one (d 1), two (d 2) and three (d 3) days of growth.

\subsection{Growth measurement}

Counting of desired initial cellular concentrations and daily counting during the tests were performed using a Malassez counting chamber, following the standard procedure ISO 10253 (AFNOR,1998). The $\mathrm{EC}_{50}$ (concentration required to cause a $50 \%$ reduction in growth) were calculated 3 days after algae inoculation. For each culture, the average specific growth rate was calculated after log transformation according to the ISO 10253 and the Excel Macro REGTOX, was applied to the growth rate to obtain the $\mathrm{EC}_{50}$ according to Vindimian et al. (1983) and Vindimian (2009).

The cell volume was determined from the length measures made by the microscope Zeiss Axiovert 135. Algae, stained with Lugol, were fixed with poly-lysine on a slide for microscopic observation. The cell volume was estimated using the Visilog software (version 6).

\subsection{Measurement of pigments}

To assure sufficient biomass, measurement of pigments was realized after 3 day culture. Diatom cells were harvested by filtration through a $0.45 \mu \mathrm{m}$ GV membrane filter (Millipore) and pigments were extracted with $100 \%$ methanol at $65^{\circ} \mathrm{C}$ during $20 \mathrm{~min}$. After cooling, the methanolic solution was centrifuged $(2,500 \mathrm{~g}, 10 \mathrm{~min})$ and its absorbance was measured at 470, 510, 630 and $664 \mathrm{~nm}$ (spectrophotometer Hitachi, U 2000). Concentrations of 
chlorophylls (a and $\mathrm{c}$ ) and total carotenoids were determined according to the methods of Jeffrey \& Humphrey (1975) and Gala \& Giesy (1993) respectively.

\subsection{Photosynthetic and respiration rates}

Gross photosynthesis and dark respiration were determined as $\mathrm{O}_{2}$ exchanges at $20{ }^{\circ} \mathrm{C}$ using a Clark-type electrode (YSI 53 Oxygen Monitor). Photosynthesis was measured under a 140 $\mu \mathrm{mol} \mathrm{m}{ }^{-2} \mathrm{sec}^{-1}$ PAR.

\subsection{Determination of ATP}

The ATP content was determined as previously described (Hourmant et al., 2009), using an ATP bioluminescent assay kit (Perkin Elmer $\left.{ }^{\circledR}\right)$. $100 \mu$ of the algal suspension were injected directly in a well of a 96-well plate and added with $50 \mu \mathrm{l}$ cell lysis solution. The plates were covered with pre-cut acetate tapes (Dynatech $®)$ and agitated for $5 \mathrm{~min}(700 \mathrm{rpm})$. After addition of $50 \mu$ luciferin-luciferase, plates were shaked for $5 \mathrm{~min}$ and incubated in the dark (10 min). Luminescence measurements were performed at the luminometer (Victor, Perkin Elmer $\left.{ }^{\circledR}\right)$ using a $10 \mathrm{~s}$ integration time. The luminescence data (relative illumination units) were converted using a calibration curve obtained with ATP dissolved in sterile seawater.

\subsection{Statistical analyses}

All experiments were conducted three or more times, data were statistically analyzed by a one-way analysis of variance (ANOVA) and, when differences observed were significant, means were compared by the multiple range Duncan test. Significant differences at a level of significance of $0.05(p<0.05)$ are represented by an asterisk $\left(^{*}\right)$. Data are given as means values \pm standard errors of the means.

\section{Results}

\subsection{Effect of epoxiconazole and formulated product (Opus) on growth}

The growth of $C$. calcitrans in pre-winter Gabès medium was much lower than in $f / 2$ medium under the both conditions of light (continuous or $16 \mathrm{~h}$ photoperiod), reaching a stationary phase at day 3 (Figures 1 and 2).
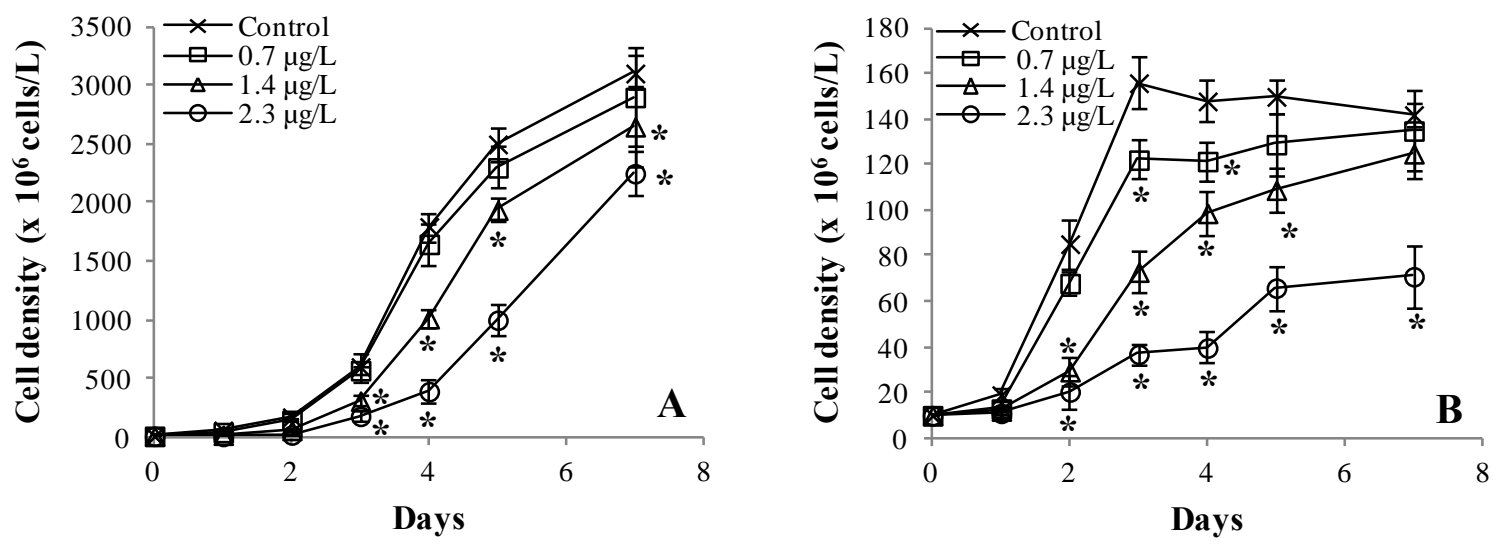

Figure 1. Growth curves for $C$. calcitrans when exposed to different concentrations of Opus under continuous light. A : f/2 medium; B : pre-winter Gabès conditions. * indicates a value significantly different at $p<0.05$. 

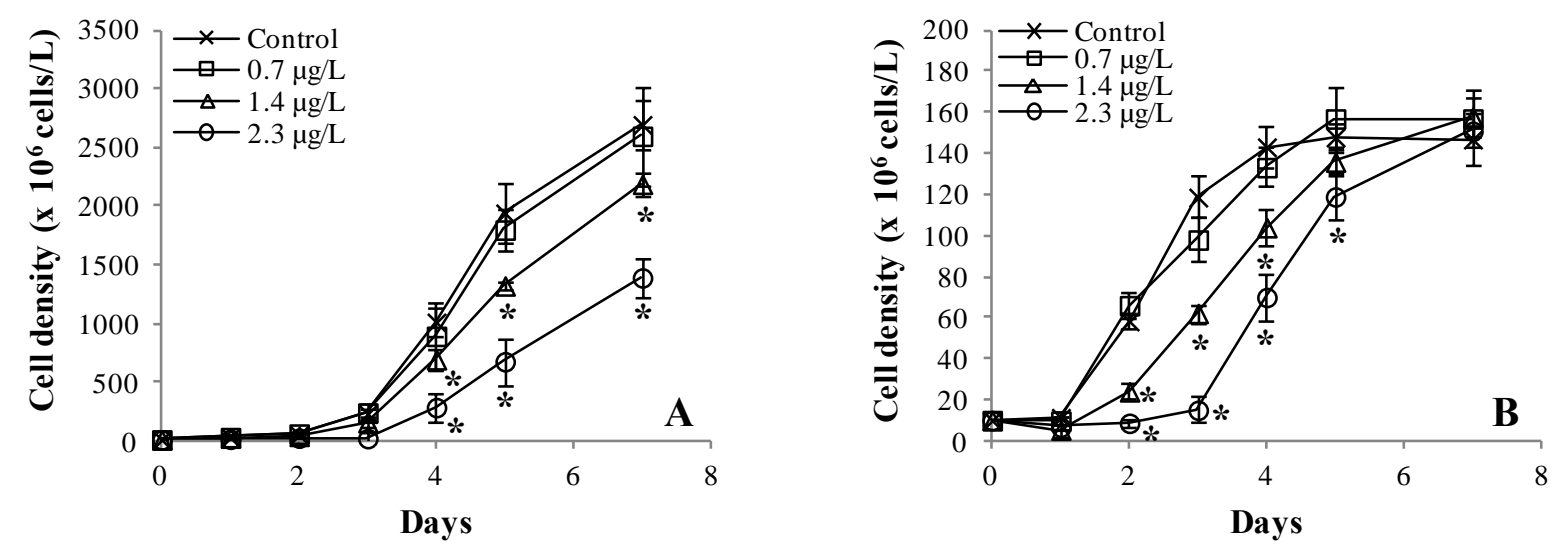

Figure 2. Growth curves for $C$. calcitrans when exposed to different concentrations of Opus under a $16 \mathrm{~h}$ photoperiod. A : f/2 medium; B : pre-winter Gabès conditions. * indicates a value significantly different at $p<0.05$.

The growth rate, evaluated after $72 \mathrm{~h}$, was maximal under continuous illumination $(0.065 / \mathrm{h})$ and minimal with a $16 \mathrm{~h}$ photoperiod $(0.011 / \mathrm{h})$ (Table 1$)$.

Table 1. Growth rate $(\mu / h \pm S E)$ of $C$. calcitrans measured after 3 days in the different culture conditions.

\section{Continuous light}

$$
0.065 \pm 0.0012
$$

$0.037 \pm 0.0049$
$16 \mathrm{~h}$ photoperiod

$$
0.045 \pm 0.011
$$

$$
0.011 \pm 0.0008
$$

Whatever the conditions of culture, addition at $\mathrm{d} 0$ of Opus, caused an immediate inhibition of the growth that increased with the fungicide concentration until 3 days (Figures 1 and 2). However, this inhibition was clearly more marked when the algae were grown in pre-winter Gabès medium. Thus, in this medium, $2.3 \mu \mathrm{g} / \mathrm{L}$ Opus inhibitions of $76 \%$ and $91 \%$ compared to $62 \%$ and $80 \%$ in $\mathrm{f} / 2$ medium, respectively under continuous light (Figure 1) and a $16 \mathrm{~h}$ photoperiod (Figure 2). From the fourth day of culture, the inhibition attenuated progressively over time but remained significant at $d 7$, being in $f / 2$ medium of $27 \%$ (Figure $1 \mathrm{~A}$ ) and $48 \%$ (Figure 2A) and, in pre-winter medium with continuous light, of $50 \%$ (Figure 2A); a total extinction of the inhibitory effect was observed under the $16 \mathrm{~h}$ photoperiod (Figure 2B).

The 3 day $\mathrm{EC}_{50}$ values obtained with Opus were estimated to be, under continuous light, 4.47 and $2.9 \mu \mathrm{g} / \mathrm{L}$, respectively with $\mathrm{f} / 2$ and pre-winter media whereas it was 3.38 and 2.63 $\mu \mathrm{g} / \mathrm{L}$ with a $16 \mathrm{~h}$ photoperiod (Table 2 ). After a 3 day-exposure to pure epoxiconazole under continuous illumination, the calculated $\mathrm{EC}_{50}$ values were 4900 and $2310 \mu \mathrm{g} / \mathrm{L}$, respectively, for $\mathrm{f} / 2$ and pre-winter media (Table 2). 
Table 2. $\mathrm{EC}_{50}(\mu \mathrm{g} / \mathrm{L})( \pm \mathrm{SE})$ of epoxiconazole obtained after 3 days growth of $C$. calcitrans grown in different culture conditions.

\begin{tabular}{clcc}
\hline & & Continuous light & 16 h photoperiod \\
\hline f/2 medium & Opus & $4.47 \pm 0.4$ & $3.38 \pm 0.29$ \\
& Epoxiconazole & $4900 \pm 460$ & - \\
Gabès medium & Opus & $2.9 \pm 0.24$ & $2.63 \pm 0.29$ \\
& Epoxiconazole & $2310 \pm 180$ & - \\
\hline
\end{tabular}

Exposure to the $2.88 \mu \mathrm{g} / \mathrm{L}$ epoxiconazole formulated product Opus, increased significantly the cell volume (Figure 3); this increase was detected at day 2, 3 and $4(70 \%, 47 \%$ and 45 $\%)$ respectively, relative to control $(p<0.05)(100 \%)$.

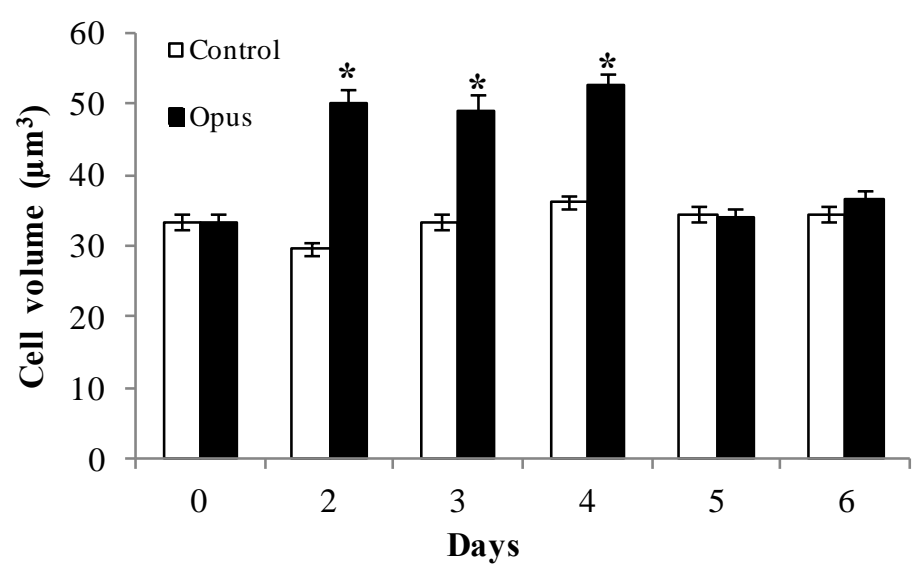

Figure 3. Influence of $2.88 \mu \mathrm{g} / \mathrm{L}$ Opus on the cell volume of $C$. calcitrans grown in a prewinter Gabès medium under continuous light. Results expressed as $\mu \mathrm{m}^{3} \pm \mathrm{SE}$. * indicates a value significantly different at $p<0.05$.

\subsection{Influence of algal development stage on Opus toxicity}

Figure 4 shows the growth curves for $C$. calcitrans when $2.3 \mu \mathrm{g} / \mathrm{L}$ Opus were added at different times of the culture. Exposure to the fungicide after 1 day of culture produced an inhibition slightly lower than the exposure from $\mathrm{d} 0$. The addition of the fungicide after 2 or 3 days of culture, produced $24 \mathrm{~h}$ later a reduction of the cell density and the growth stopped. 


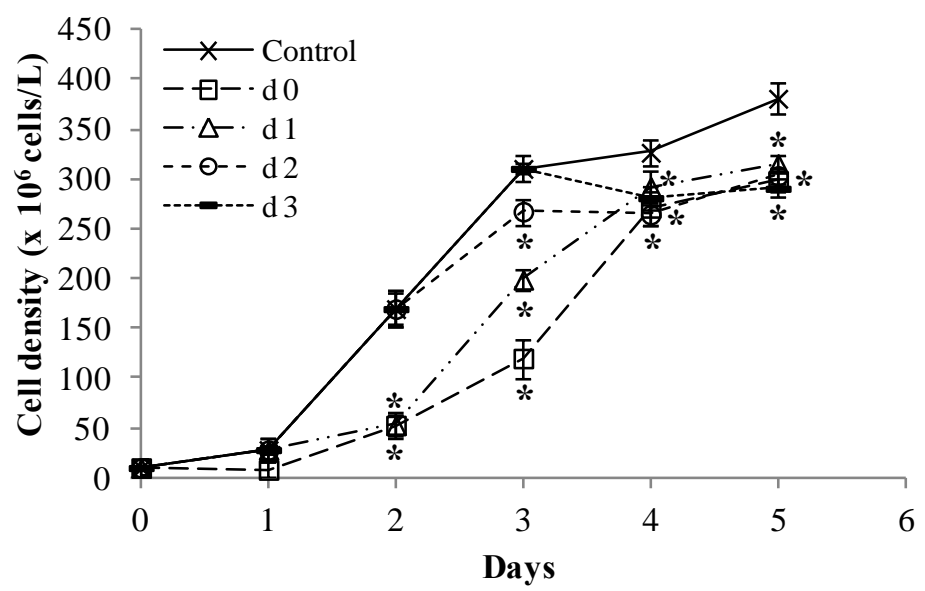

Figure 4. Growth curves for $C$. calcitrans in pre-winter Gabès medium when exposed to 2.3 $\mu \mathrm{g} / \mathrm{L}$ Opus, added at different stages of development $(\mathrm{d}=$ day). Cultures under continuous illumination. * indicates a value significantly different at $p<0.05$.

\subsection{Effect of Opus on pigment content}

The pigment alterations produced by Opus in C. calcitrans cultured in the pre-winter medium for 3 days are summarized in Table 3 . A significant increase in chlorophylls and carotenoids occurred when the fungicide was added at $d 0$ and, to a lesser extent, when added at $d 1$. A tendency of stimulation was still observed when Opus was added at $d 2$.

Table 3. Effect of $2.16 \mu \mathrm{g} / \mathrm{L}$ Opus added at different stages of growth on the pigment content of $C$. calcitrans measured after 3 days of culture under continuous illumination. Results expressed as ng / million cells $\pm \mathrm{SE}$, value in parentheses indicates the percentage relative to the control. * indicates a value significantly different at $p<0.05$.

\begin{tabular}{cccc}
\hline & Chlorophyll a & Chlorophyll c & Carotenoids \\
\hline Control & $70.83 \pm 8.67$ & $25.06 \pm 5.42$ & $53.15 \pm 3.08$ \\
+ Epoxi. at day & $97.35 \pm 9.21(137$ & $37.30 \pm 3.81(149$ & \\
0 & $\%)^{*}$ & $\%)^{*}$ & \\
+ Epoxi. at day & $91.26 \pm 6.43(129$ & $33.90 \pm 3.54(135$ & $64.26 \pm 4.87(121 \%)^{*}$ \\
1 & $\%)^{*}$ & $\%)^{*}$ & \\
+ Epoxi. at day & $74.48 \pm 7.62(105 \%)$ & $27.60 \pm 4.22(110 \%)$ & $57.71 \pm 3.90(108 \%)$ \\
2 & & &
\end{tabular}




\subsection{Effect of Opus on photosynthetic and respiration rates}

The time responses of gas exchanges in C. calcitrans grown in pre-winter medium and continuous illumination are shown in Figure 5.
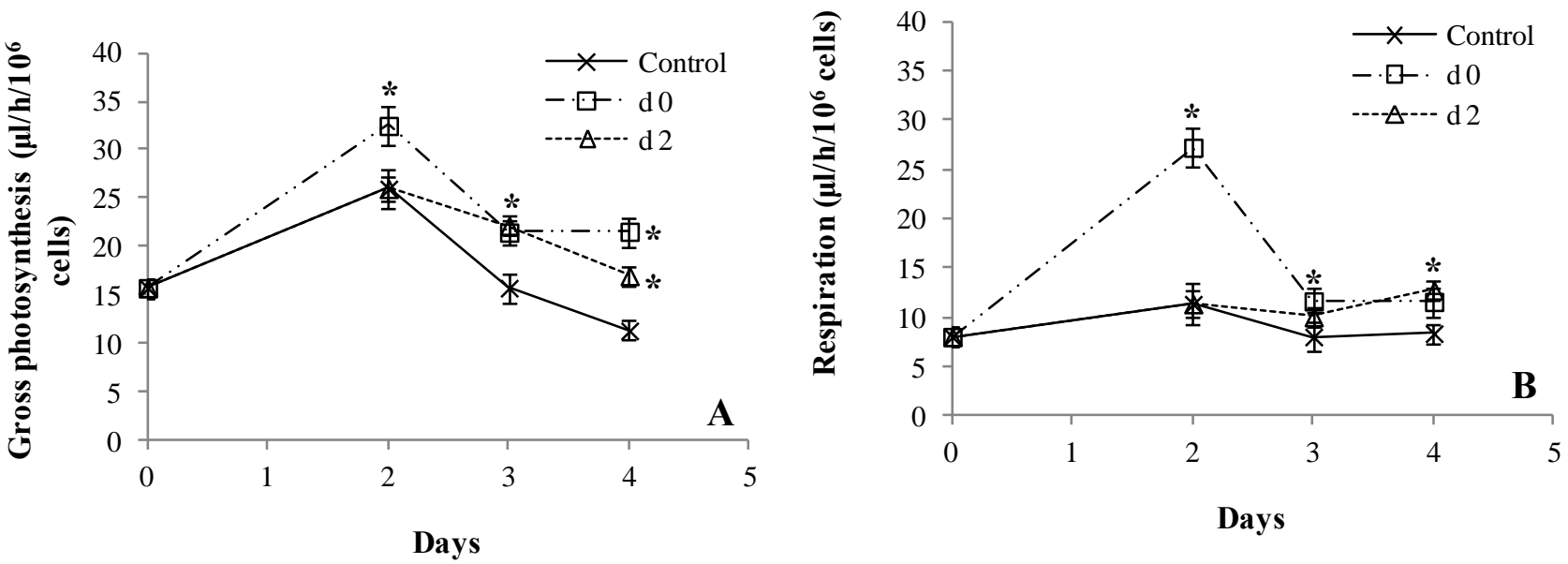

Figure 5. Oxygen exchanges obtained in cultures of $C$. calcitrans exposed to $2.3 \mu \mathrm{g} / \mathrm{L}$ of Opus added at the beginning ( $(\mathrm{d} 0)$ or after two days ( $(\mathrm{d} 2)$ of culture in pre-winter Gabès medium under continuous illumination. (A) photosynthesis ; (B) respiration. * indicates a value significantly different at $p<0.05$.

In control cultures, after a large increase in photosynthesis occurring after 2 days, (Figure $5 \mathrm{~A}$ ), the rate returned to its initial value and then declined. The same tendency was observed for the respiration rate (Figure $5 \mathrm{~B}$ ). Opus $(2.3 \mu \mathrm{g} / \mathrm{L})$ added at $\mathrm{d} 0$, increased significantly gas exchanges. The stimulation of photosynthesis, $+25 \%$ after the 2-day exposure, significantly increased afterwards. The respiration stimulation, maximal after 2 days of incubation $(+140$ $\%)$, tends to attenuate with time. When added after 2 days of culture, Opus produced 1 day later, a significant increase of photosynthesis (+ $40 \%)$ and respiration (+ $45 \%)$ that was still observed after the 2-day exposure.

\subsection{Effect of Opus on ATP content}

In control culture, a peak in ATP production was observed after 1 day of culture which decreased gradually afterwards (Figure 6).

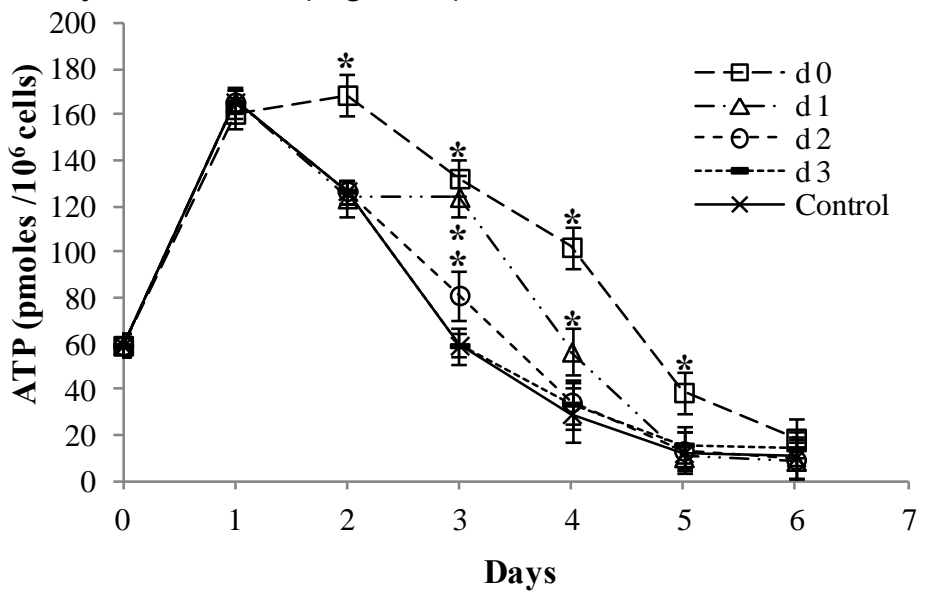

Figure 6. Influence of $2.3 \mu \mathrm{g} / \mathrm{L}$ Opus added at different stages of growth on the ATP content of $C$. calcitrans cultivated in pre-winter Gabès medium under continuous illumination $(\mathrm{d}=$ day). ${ }^{*}$ indicates a value significantly different at $p<0.05$. 
Exposure to $2.3 \mu \mathrm{g} / \mathrm{L}$ Opus at the start of the culture, maintained the peak value for 2 days and delayed the decline in ATP amount, giving rise to a significant stimulation of the ATP, maximal at day $4(+253 \%)$. When Opus was added after 1 day of culture, it produced 2 days later a significant increase of the ATP content (+ $109 \%)$, that slowed down later on. Added after 2 or 3 days of culture, the fungicide produced 1 day later a slight stimulation (+ $37-35 \%$ ) of the ATP content, disappearing later on.

\section{Discussion}

The sensitivity of $C$. calcitrans to epoxiconazole and its formulation (Opus) was examined, and the influence of the nutrient level, light photoperiod and cell age was studied. Whatever the conditions of growth, an immediate progressive reduction of cell density was produced by increasing epoxiconazole concentration. However, after a 3 day inhibitory growth period, a progressive extinction of the inhibitory effect of fungicide was observed.

Under continuous light, with a f/2 medium or with a pre-winter Gabès medium, the 3 day $E_{50}$ for the formulated product (respectively 4.47 and $2.9 \mu \mathrm{g} / \mathrm{L}$ ) were in both cases three orders of magnitude below the pure compound's $\mathrm{EC}_{50}$ (respectively 4.9 and $2.31 \mathrm{mg} / \mathrm{L}$ ). These results questioned the use of ecotoxicological data obtained solely using active molecules of pesticides rather the complete formulation because it is the formulation that goes to the marine ecosystem. As shown by several authors, surfactants and so-called "inert" components can contribute to the overall toxicity of the formulation either by exerting toxic activity of the formulation on their own, or by interacting with the active ingredient (Caux et al., 1996; Oakes \& Pollak, 2000; Martin Tsui \& Chu, 2003; Hourmant et al., 2009; Pereira et al., 2009; Lipok et al., 2010). The $\mathrm{EC}_{50}$ of the pure molecule are within expected values reported in the literature about toxic effects of other triazole fungicides. Baird \& DeLorenzo (2010) obtained for the chlorophyceae Dunaliella tertiolecta $96 \mathrm{~h} \mathrm{EC}_{50}$ ranging between 0.91 to $5.98 \mathrm{mg} / \mathrm{L}$ with hexaconazole, propiconazole, triadimenol and triadimefon. In contrast, the $72 \mathrm{~h} \mathrm{EC}_{50}$ value for Pseudokirchneriella subcapitata (> $10 \mathrm{mg} / \mathrm{L}$ ) with epoxiconazole suggests a lower toxicity towards freshwater algae (AGRITOX, 2010).

The growth rate and the inhibitory effect of epoxiconazole are dependent on nutrient level and light intensity. Thus, under optimal growth conditions ( $\mathrm{f} / 2$ medium, continuous light),

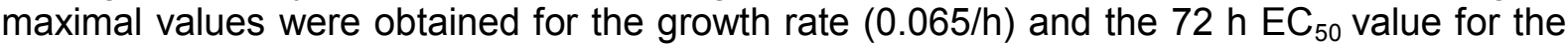
formulated product $(4.47 \mu \mathrm{g} / \mathrm{L})$. By contrast, minimal values were obtained under a $16-\mathrm{h}$ photoperiod with the pre-winter Gabès medium, being for $\mu: 0.011 / \mathrm{h}$ and $\mathrm{EC}_{50}: 2.63 \mu \mathrm{g} / \mathrm{L}$. When the cell density is high, less fmoles epoxiconazole per cell are available and this could explain the higher toxic effect of the fungicide when the growth was limited either by light or by nutrient concentration. This is in agreement with data about $\mathrm{Cr}$ reported by Sbrilli et al. (2003).

As shown on growth curves, after a 3-day epoxiconazole exposure, the cells of $C$. calcitrans try to increase the growth rate, after a strong inhibitory growth period. Metabolism of epoxiconazole in plants as well as in soil has been shown to be limited (Bromilow et al., 1999; Lin et al., 2001; Buerge et al., 2006; EFSA, 2008; Passeport et al., 2011). The increasing cell density occurring with time decreases the amount of epoxiconazole available per cell and allows the alleviation of inhibition to take place. Moreover, the lower inhibition displayed by epoxiconazole added during the exponential growth confirms that cellular density is a very important parameter in toxicity. These results are in accordance with data about Cu reported by Moreno-Garrido et al. (2000). However, the differences in susceptibility to this sterol-inhibiting fungicide might also result from the changes in lipid composition with growth stage, as suggested by Tuckey et al. (2002). 
Growth rate is often closely related to energy production. Interestingly, while growth inhibition was clearly observed, epoxiconazole (added at day 0 or 1 ) increases the oxygen exchanges and delays the decline in ATP that occurs in the control after day 1. This may suggest that ATP produced was not use to cope with growth requirements and, as a consequence, accumulates within the cell.

The pigment content was significantly increased by epoxiconazole, added at the start of the culture or 1 day later, and may explain the higher photosynthesis activity observed. Examples of herbicide-induced increase of algal chlorophyll content have been reported in freshwater (Mayer \& Jensen, 1995; Rioboo et al., 2002) and marine microalgae (Hourmant et al., 2009). The mechanism of toxicity is therefore probably not an interference with formation or maintenance of pigments but with other essential process. In many higher plants, a reduction of growth by triazole compounds has also been shown, accompanied by increases of pigments and photosynthesis (Percival \& Noviss, 2008; Jaleel et al., 2008 and references therein) but a reduction of in vitro thylacoid activity has been reported in Galium aparine, although chlorophyll was increased on a unit area basis (Benton \& Cobb, 1997).

Cell volume of $C$. calcitrans was increased by epoxiconazole and this may be related to the growth inhibition and therefore influence the remaining parameters, pigment and ATP content. Previous studies indicate that algal cell volume is highly correlated with toxicity (Tang et al., 1998; Rioboo et al., 2002; Hourmant et al., 2009) and the swelling of Dunaliella tertiolecta exposed to conazole fungicides likely attributable to altered membrane structure resulting from a large increase of total lipid content (Baird \& DeLorenzo, 2010).

Our results suggest that epoxiconazole, known as an inhibitor of ergosterol biosynthesis, could be affecting the mechanisms of cell division, but not the production of new material for the construction of new cells. Consequently, the reduction of growth rate might be caused by a prolongation of the cell cycle, cellular density being an important parameter in the sensitivity to the fungicide.

\section{Conclusions}

Exposure of $C$. calcitrans to the sterol biosynthesis inhibiting fungicide epoxiconazole, reduces the growth rates while increasing the cell volume, and toxicity of the formulation was markedly higher. This fungicide increases pigment content and thereby photosynthesis and ATP production. When the growth rate was increased by continuous illumination and nutrient level, the sensitivity of $C$. calcitrans to epoxiconazole was decreased. A progressive algal cell recovery from epoxiconazole effects occurred after 3 days, with the increasing cell density. When the toxic was given during the exponential phase, its effects were weakened. These results suggest that cellular density is an important parameter in toxicity tests.

Based on these results, one can say that a non-target marine microalgae may be affected by a fungicide. Because algae serve as primary producers within marine ecosystems, they could be influence organisms that feed in the food chain.

\section{References}

AFNOR. (1998) Qualité de l'eau - Essai d'inhibition de la croissance des algues marines avec Skeletonema costatum et Phaeodactylum tricornutum. NF EN ISO 10253, T90-311, 8p. 
AGRITOX. (2010) Base de données sur les substances actives phytopharmaceutiques www.dive.afssa.fr/agritox/index.php

Akcha F., Arzul G., Rousseau S. and Bardouil M. (2008) Comet assay in phytoplancton as biomarker of genotoxic effects of environmental pollution. Marine Environmental Research $66,59-61$.

Akers A., Köhle H. and Gold R.E. (1990) Uptake, transport and mode of action of BAS 480 F, a new triazole fungicide. Brighton Crop Protection Conference - Pests and diseases 2, 837-845.

Ammermann E., Lorenz G., Schelberger K., Sauter H. and Rentzea C. (1992) A broadspectrum fungicide with a new mode of action. Brighton Crop Protection Conference - Pest and diseases 1, 403-410.

Baird T.D. and DeLorenzo M.E. (2010) Descriptive and mechanistic toxicity of conazole fungicides using the model test alga Dunaliella tertiolecta (Chlorophyceae). Environmental Toxicology 25, 213-220.

Benton J.M. and Cobb A.H. (1997) The modification of phytosterol profiles and in vitro photosynthetic electron transport of Galium aparine L. (Cleavers) treated with the fungicide, epoxiconazole. Plant Growth Regulation 22, 93-100.

Bertelsen J.R., de Neergaard E. and Smedegaard-Petersen V. (2001) Fungicidal effects of azoxystrobin and epoxiconazole on phyllosphere fungi, senescence and yield of winter wheat. Plant Pathology 50, 190-205.

Bromilow R.H., Evans A.A. and Nicholls P.H. (1999) Factors affecting degradation rates of five triazole fungicides in two soil types : 2. Field studies. Pesticide Science 55, 1135-1142.

Buerge I.J., Poiger T., Müller M.D. and Buser H.D. (2006) Influence of pH on the stereoselective degradation of the fungicides epoxiconazole and cyproconazole in soils. Environmental Science and Technology 40, 5443-5450.

Caux P. Y., Ménard L., and Kent R. A. (1996) Comparative study of the effects of MCPA, butylate, atrazine, and cyanazine on Selenastrum capricornutum. Environmental Pollution 92, 219-225.

EFSA Scientific Report. (2008) Conclusion on the peer review of epoxiconazole 138, 1-80.

Gala W.R. \& Giesy J.P. (1993) Using the carotenoid biosynthesis inhibiting herbicide, fluridone, to investigate the ability of carotenoid pigments to protect algae from the photoinduced toxicity of anthracene. Aquatic Toxicology 27, 61-70.

Guillard R.R.L. and Ryther J.H. (1962) Studies of marine planktonic diatoms Cyclotella nana Hustedt and Detonula confervacea Cleve. Canadian Journal of Microbiology 8, 229239.

Hourmant A., Amara A., Pouline P., Durand G., Arzul G. and Quiniou F. (2009) Effect of bentazon on growth and physiological responses of marine diatom: Chaetoceros gracilis. Toxicology, Mechanisms and Methods 19, 109-115.

Jaleel C.A., Gopi R. and Panneerselvann R. (2008) Growth and photosynthetic pigments responses of two varieties of Catharantus roseus to triadimefon treatment. Comptes Rendus de Biologies 331, 272-277. 
Jeffrey S.W. and Humphrey G.F. (1975) New spectrophotometric equations for determining chlorophyll a, b, $\mathrm{c}_{1}$ and $\mathrm{c}_{2}$ in higher plants, algae and natural populations. Biochemie und Physiology der Pflanzen 167, 191-194.

Kwok I.M.Y. and Loeffler R.T. (1993) The biochemical mode of action of some newer azole fungicides. Pesticide Science 39, 1-11.

Lin H.T., Wong S.S. and Li G.C. (2001) Dissipation of epoxiconazole in the paddy field under subtropical conditions of Taiwan. Journal of Environmental Science and Health B36, 409-420.

Lipok J., Studnik H. and Gruyaert S. (2010) The toxicity of Roundup ${ }^{\circledR} 360$ SL formulation and its main constituents: Glyphosate and isopropylamine towards non-target photoautotrophs. Ecotoxicology and Environmental Safety 73, 1681-1688.

Mayer P. and Jensen J.F. (1995) Factors affecting results of algal toxicity tests. Institute for Environmental Science and Technology. Technical University of Denmark, Lyngby.

Martin Tsui T.K. and Chu L.M. (2003) Aquatic toxicity of glyphosate-based formulations : comparison between different organisms and the effects of environmental factors. Chemosphere 52, 1189-1197.

Moreno-Garrido L., Lubiăn L.M. and Soares A.M.V.M. (2000) Influence of cellular density on determination of EC50 in microalgal growth inhibition tests. Ecotoxicology and Environmental Safety 47, 112-116.

Nørgaard K.B. and Cedergreen N. (2010) Pesticide cocktails can interact synergically on aquatic crustaceans. Environmental Science and Pollution Research 17, 957-967.

Oakes D.J. and Pollak J.K. (2000) The in vitro evaluation of the toxicities of three related herbicide formulations containing ester derivates of 2,4,5-T and 2,4-D using submitochondrial particles. Toxicology 151, 1-9.

Passeport E., Benoit P., Bergheaud V., Coquet Y. and Tournebize J. (2011) Epoxiconazole degradation from artificial wetland and forest buffer substrates under flooded conditions. Chemical Engineering Journal 173, 760-765.

Percival G.C. and Noviss K. (2008) Triazole induced drought tolerance in horse chestnut (Aesculus hippocastanum). Tree Physiology 28, 1685-1692.

Pereira J.L., Antunes S.C., Castro B.B., Marques C.R., Gonçalves A.M.M., Gonçalves F. and Pereira R. (2009) Toxicity evaluation of three pesticides on non-target aquatic and soil organisms : commercial formulation versus active ingredient. Ecotoxicology 18, 455-463.

Rioboo C., Gonzalez O., Herrero C. and Cid A. (2002) Physiological response of freshwater microalga (Chlorella vulgaris) to triazine and phenylurea herbicides. Aquatic Toxicology 59, 225-235.

Sbrilli G., Calamati E., Boccalini S., Bimbi B. and Pistolesi F. (2003) Effects of nutrients and salinity on the algal assay using Pseudokirshneriella subcapitata (Korshikov) Hindak. Bulletin of Environmental Contamination and Toxicology 71, 609-616.

Schöfl U.A. and Zinkernagel V. (1997) A test method based on microscopic assessments to determine curative and protectant fungicide properties against Septoria tritici. Plant Pathology 46, 545-556. 
Stachowski-Haberkorn S., Quiniou F., Nédélec M., Robert R., Limon G. and de la Broise D. (2008) In-situ microcosms, a tool for assessment of pesticide impacts on oyster spat (Crassostrea gigas). Ecotoxicology 17, 235-245.

Stachowski-Haberkorn S., Quiniou L., Beker B., Haberkorn H., Marie D. and de la Broise D. (2009) Comparative study of three analysis methods (TTGE, flow cytometry and HPLC) for xenobiotic assessment on phytoplancton communities. Ecotoxicology 18, 364376.

Tang J., Hoagland K.D. and Siegfried B.D. (1998) Uptake and bioconcentration of atrazine by selected freshwater algae. Environmental Toxicology and Chemistry 17, 1085-1090.

Tomlin C.D.S. (1999) The pesticide manual. $12^{\text {th }}$ edn, British crop protection council. Farnham, Surrey, UK.

Tuckey D.M., Orcutt D.M. and Hipkins P.L. (2002) Inherent and growth stage-related differences in growth and lipid composition of algal species sensitive and tolerant to sterolinhibiting fungicides. Environmental Toxicology and Chemistry 21, 1715-1723.

Vindimian E. (2009) MSExcel macro REGTOX_EV7.0.5.xls; http://www.normalesup.org/ vindimian/DOC_fr_web/doc_fr_2.html.

Vindimian E., Robaut C. and Fillion G. (1983) A method for cooperative binding studies using non linear regression analysis on a microcomputer. Journal of Applied Biochemistry 5, 261-268.

Wu Y.X. and von Tiedemann A. (2001) Physiological effects of azoxystrobin and epoxiconazole on senescence and the oxidative status of wheat. Pesticide Biochemistry and Physiology 71, 1-10.

Zeitzschel B. (1978) Why study phytoplancton ? In Sournia A. (ed) Phytoplankton manual. UNESCO, Paris, France, pp. 1-5. 